\title{
ENHANCEMENT OF SOLAR STILL EFFICIENCY BY USING CELLULOSE COOLING PAD AND WATER SPRINKLER
}

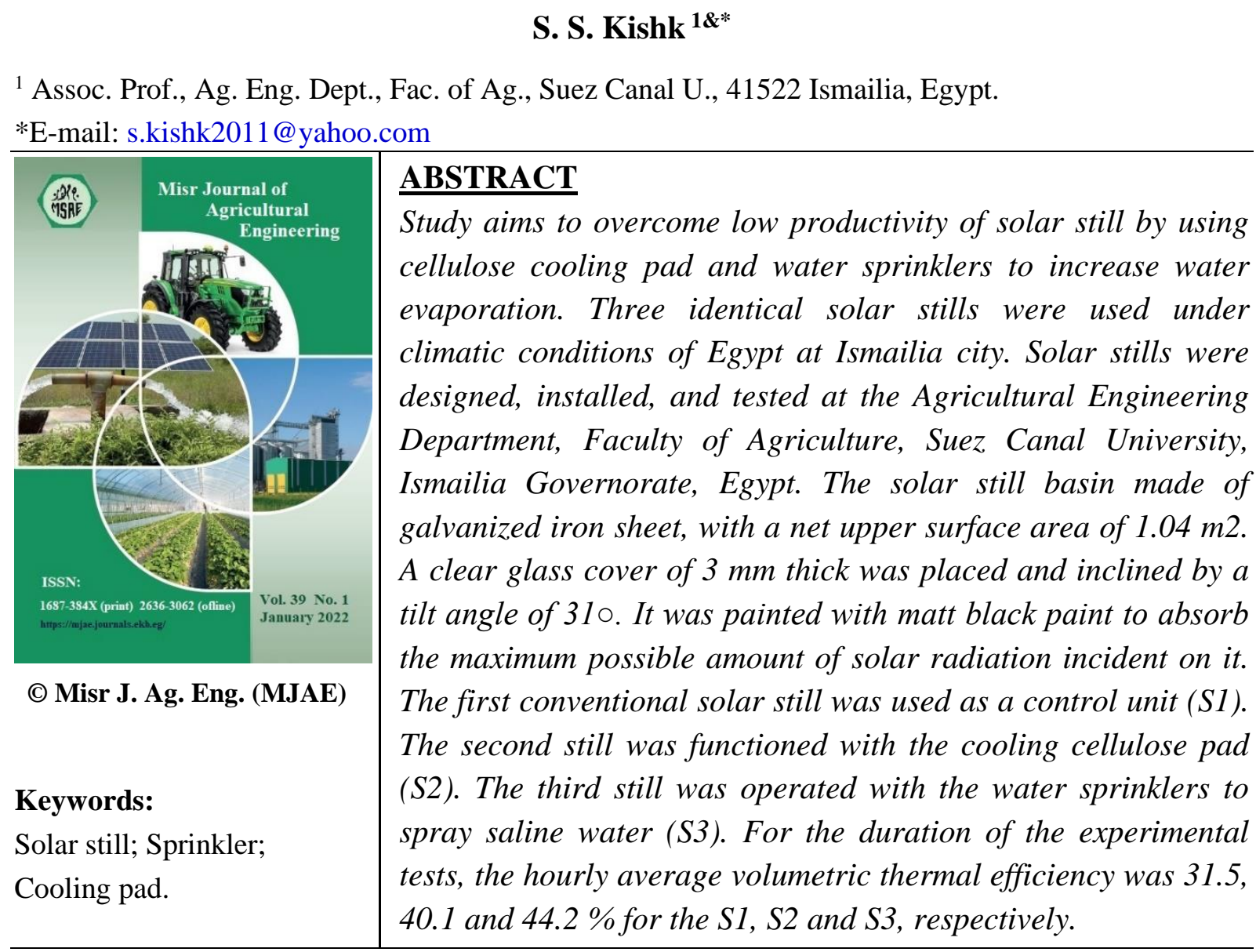

\section{INTRODUCTION}

$\mathrm{F}$ uels are the world main energy resource and considered the center of energy demands. However, reserves of fossil fuels are limited and their large-scale use is associated with environmental deterioration. These facts have encouraged growth in the use of renewable energy resources (Taha and Helal 2020). To solve dependency on fossil fuels researchers and governments are working tirelessly on renewable energy which should be commercially viable, pollutant free and must be abundant in nature (Chukwujindu, 2017). The energy from the sun intercepted by the earth is many thousands of times larger than the present consumption rate on the earth of all commercial sources (Nandurkar and Shelke, 2012). One of the simplest and most direct applications of this energy is the conversion of solar radiation into heat (Kishk and Abu-Zeid 2019). The solar distillation is one of the most important methods for producing fresh water from brackish and sea water using the free and friendly energy supply (solar energy). Supplying fresh and healthy water is still one of the major problems in different parts of the world, especially in arid remote areas. Solar stills can solve a part of the problem in those areas where solar energy is available (El-Sheikh and Kishk, 2016). Supplying fresh and healthy water is still one of the major problems in different parts of the world, especially in arid remote areas. Solar still is one of the best solutions to 
solve water problem in remote arid areas. This device is not popular because of its lower productivity. One of the methods to increase the productivity is by increase the water evaporation area. The solar distillation is one of the most important methods for producing fresh water from brackish and sea water using the free and friendly energy supply (solar energy). These units can be placed at each house for producing at least drinking water (Arjunan et al., 2009). Solar desalination is a process of separating pure water from saline water using solar energy (Sakthivel et al., 2010). This inexpensive device can easily be built using local materials (Kantesh, 2012). There is a strong need to improve the solar still performance and increase the production of water distillation (Sundaram et al., 2016). Single slope solar stills are one of the solar devices used for freshwater production. They are considered as one of the cheapest solutions for purifying saline water and suitable for the Middle East and Africa due to their easily constructive approach and maintenance (Goosen $\boldsymbol{e t}$ al., 2000). Kabeel $\boldsymbol{e t}$ al. (2010) used different methods and modifications to improve the productivity of solar stills. The results showed that the best average and maximum daily productivity are obtained from solar stills of single slope shape. Bassam et al. (2003) proposed a modification to enhance the distillate production by placing sponge cubes over the water surface. The sponge cubes increased the surface area over which evaporation of water occurs hence caused the increase of yield by $18 \%$. The cover with inclination equal to latitude angle will receive the sun rays close to normal throughout the year. For places with latitude higher than $20^{\circ} \mathrm{N}$, single slope still is preferable (Fath et al., 2003). Heat transfer within the solar still depends mainly on the evaporative surface area and the temperature difference between the evaporative surface temperature and the condensing surface temperature (Rai et al., 2013). Singh and Tiwari (2004) found that the annual yield of the solar still was maximized when the condensing glass cover inclination is equal to the latitude of the place. Abd Elkader (1998) found that the optimum inclined angle for solar still was $30-35^{\circ}$ for Port Said/Egypt (latitude angle of $31.2^{\circ} \mathrm{N}$ ). Murugavel et al. (2008) found that the solar still with glass cover plate with $3 \mathrm{~mm}$ thick gives $16.5 \%$ more production than that covered with $6 \mathrm{~mm}$ thick glass cover. The basin water depth is also having a significant effect on productivity of the basin. Experiments with deep basin reveal that the productivity of the still decreases with an increase in depth of water during daylight (Rajesh and Tiwari, 2005). Phadatare and Verma (2007) studied Influence of water depth on internal heat and mass transfer in a plastic solar still. Investigations show that, the water depth is inversely proportional to the productivity of still. El-Zahaby et al. (2011) studied the still performance using a spray feeding system. They found the sprayed system improving the performance along the whole daytime and, particularly, on the morning hours. Several works were carried out by researchers, to improve the production capacity of the still, by adopting different techniques. The basin water depth is having significant effect on productivity of the solar still. Investigations show that, the water depth is inversely proportional to the productivity of still (Phadatare and Verma, 2007). If the water surface in the basin is exposed to larger area, the evaporation rate is high. The water surface area can be increased by employing suitable wick and porous materials in the basin. The performance of a solar still with different size of sponge cubes placed on the basin was studied experimentally by (Abu-Hijleh and Rababa'h, 2003). The increase in distillate production of the still was from $18 \%$ to $27 \%$ compared to a 
conventional still. The study is aimed to overcome the low efficiency of solar still by using cooling cellulose pad and water sprinkler to increase the saline water evaporation, under climatic conditions of Egypt at Ismailia city.

\title{
2. MATERIALS AND METHODS
}

\section{Experimental setup}

Three simple basin-type solar stills each having similar basin area were constructed and tested at Department of Agricultural Engineering, Faculty of Agriculture, Suez Canal University, Ismailia Governorate, Egypt (latitude angle of $30.62^{\circ} \mathrm{N}$, Longitude angle of $32.27^{\circ} \mathrm{E}$, and mean altitude above the sea level of $5 \mathrm{~m}$ ). The schematic diagram and the pictorial view of the solar still units and components are shown in Figs (1 and 2), respectively. The geometric characteristics of each still are as follows: width, $0.8 \mathrm{~m}$, length, $1.3 \mathrm{~m}$, basin depth, $0.1 \mathrm{~m}$, basin surface area, $1.04 \mathrm{~m}^{2}$. The still basin shape is rectangular and made of galvanized iron sheet. It is painted by matt-type black to maximize the absorbed solar radiation. A clear glass cover of $3 \mathrm{~mm}$ thick was placed and inclined by a tilt angle of $31^{\circ}$ to transmit the maximum possible of solar radiation flux incident on it (Singh and Tiwari, 2004).

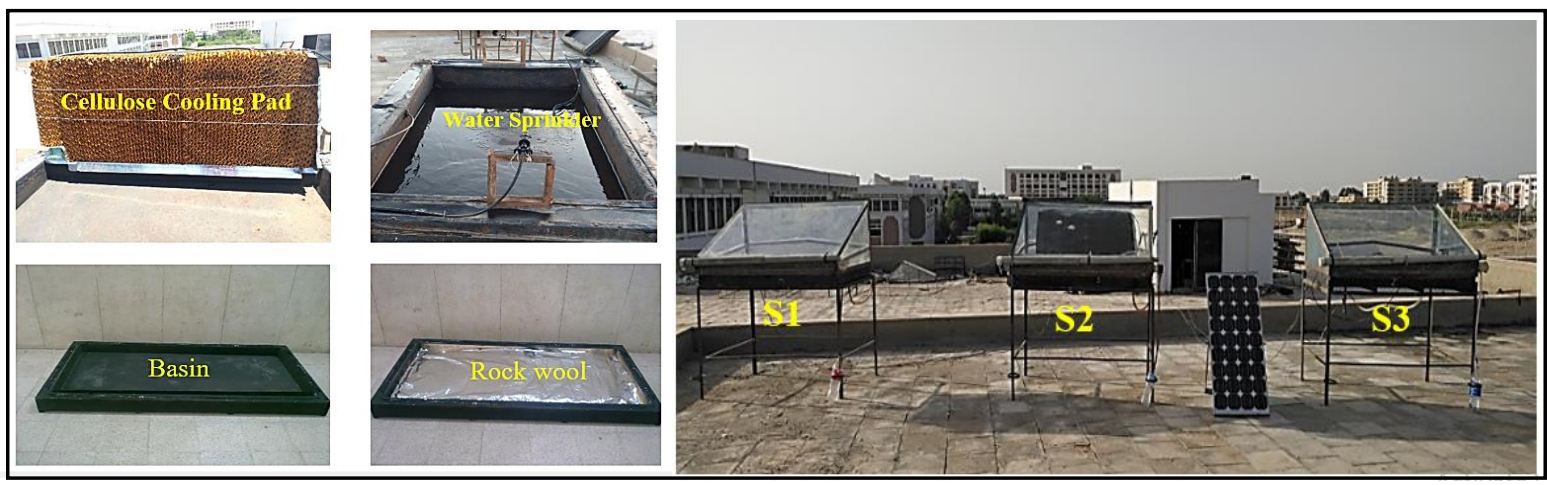

Fig. (1): A photo of the three single slope solar stills and still components
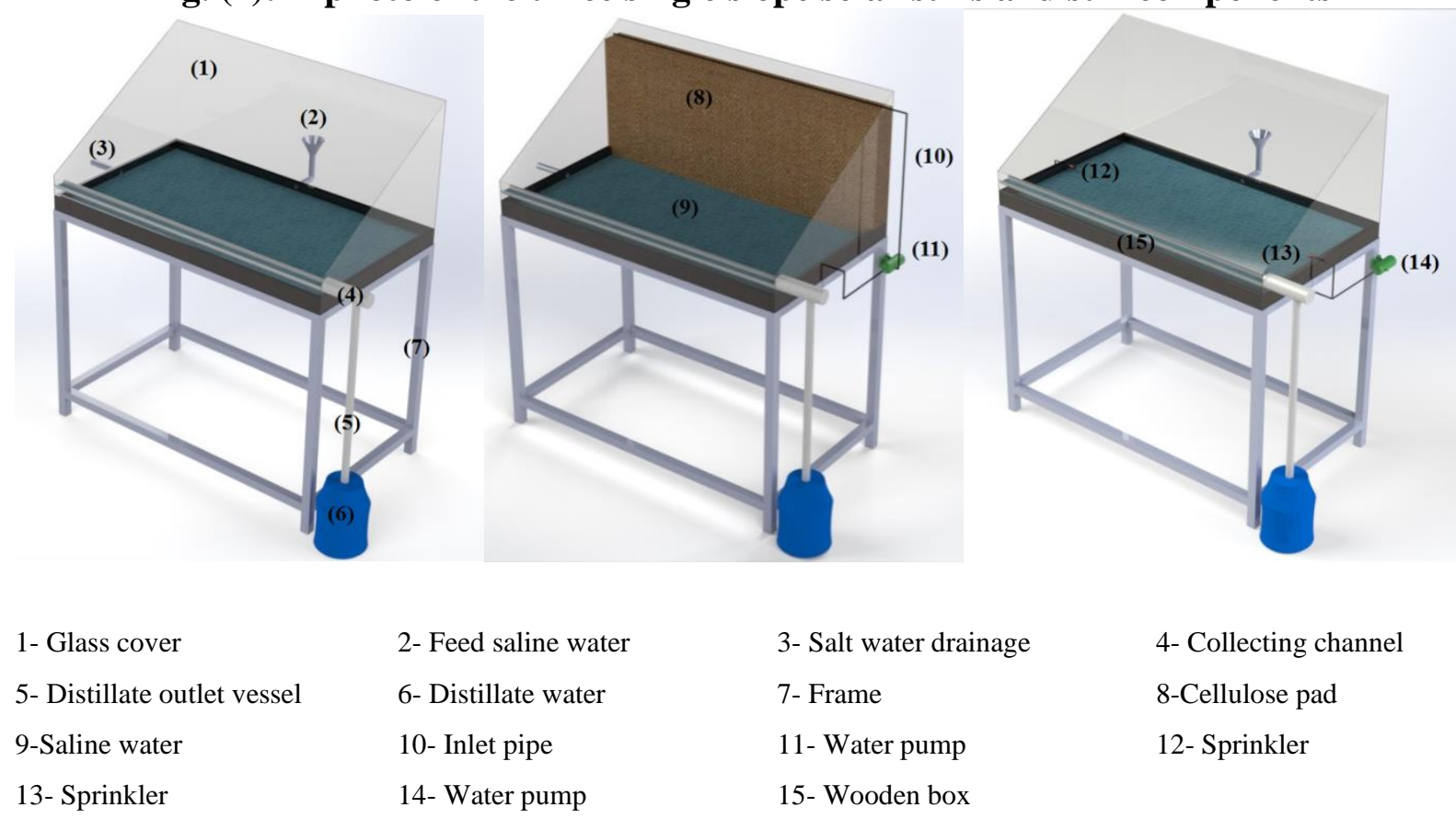

\begin{abstract}
2- Feed saline water
6- Distillate water

10- Inlet pipe
\end{abstract}

3- Salt water drainage

4- Collecting channel

7- Frame

8-Cellulose pad

11- Water pump

12- Sprinkler

Fig. (2): Schematic diagram of experimental setup of solar stills 
The slope was adjusted to $31^{\circ}$, which is considered adequate for geographical location of Ismailia city. With this inclined angle $\left(31^{\circ}\right)$, the condensates will run down underneath the glass cover into the trough rather than dropping from the cover into the basin. Glass cover has been sealed with silicone rubber which plays an important role to promote efficient operation of condensation as it can accommodate the expansion and contraction between dissimilar materials. To minimize heat loss from the base and the sides of the still basins, each galvanized basin was fitted inside a wooden frame. The gaps between each wooden and galvanized basin were packed with $0.05 \mathrm{~m}$ thick of rock wool (thermal conductivity $=0.0346$

$\mathrm{Wm}^{-1} \mathrm{~K}^{-1}$ ) for the outside walls and bottom. To collect the distilled water from the solar still, a trough made from PVC was placed along the bottom side of the glass cover with an inclination of $5^{\circ}$ towards the collecting head to speed up the condensate velocity and to avoid the tendency of re-evaporation. The system has capability to collect distillates from all sides of the solar stills. The distilled water is continuously collected in a plastic vessel located outside the still and measured using a graduated cylinder. A steel pipe is used to supply the saline water fixed at the side wall of the still for feeding saline water. The cooling cellulose pad system consists of cellulose pad and water pump connected with still basin by fixable plastic tube (6 mm diameter). Cellulose pad plate has a gross dimension of $40 \mathrm{~cm}$ high, 120 $\mathrm{cm}$ wide and $10 \mathrm{~cm}$ thick with net surface area of $0.48 \mathrm{~m}^{2}$. Cellulose pad plate placed vertically in the opposite inclined wall (Northern direction) in the solar still.

Water can be recycled to the cellulose pad by a DC water pump (30 W, $24 \mathrm{~V}$, and 2 litres per minute discharge). The pump related to plastic pipe installed on the upper part of pad to recirculate water from the basin to the pad again. Twenty holes were drilled about $6 \mathrm{~cm}$ apart along the top side of plastic pipe, and the end of this pipe was capped. The spray system consists of two sprinklers installed at the sides of solar still and connected with the still basin by a DC water pump $(30 \mathrm{~W}, 24 \mathrm{~V})$ and fixable plastic tube $(6 \mathrm{~mm}$ diameter $)$ to recirculate water from basin to the sprinklers again. The saline water is continually sprayed at constant flow rate $65 \mathrm{ml} / \mathrm{min}$ for each sprinkler. Photovoltaic module of a nominal power of a $75 \mathrm{~W}$ and circuit voltage $24 \mathrm{~V}$ was used within the experimental task of this study. The module was made by Siemens Solar Company, American made. The solar stills and solar module were faced the south direction and inclined by a tilt angle of $31^{\circ}$ to transmit the maximum possible of solar radiation flux incident on it.

\section{Measurements and data acquisition}

The investigation was carried out on sunny days throughout July month of summer 2020 under Ismailia city climatic conditions. The experiments were conducted from sunrise to sunset and all the three stills were operated simultaneously. The experimental procedure commenced by cleaning dust from the external glass covers and the collected water was measured each one hour during daylight. Meteorological station (Vantage Pro 2, Davis, USA) located above the roof of the Agricultural Engineering Department was used to measure different macroclimate variables such as solar radiation flux incident on a horizontal surface (pyranometer), dry-bulb, wet-bulb, and dew-point air temperatures as shown in Fig (3). Twelve thermocouples with a range of 0 to $100^{\circ} \mathrm{C}$ with an accuracy of $\pm 0.1^{\circ} \mathrm{C}$ were functioned to measure the temperatures of various points of each solar still system (basin water temperature $\left(\mathrm{T}_{\mathrm{w}}\right)$ vapour temperature $\left(\mathrm{T}_{\mathrm{v}}\right)$ inside glass temperature and ambient air 
temperature (Ta)). These sensors were connected to a data-logger system (a 12-chanels data logger device, Digi-sense scanning thermometer type) to display, and record the data during the experimental period.

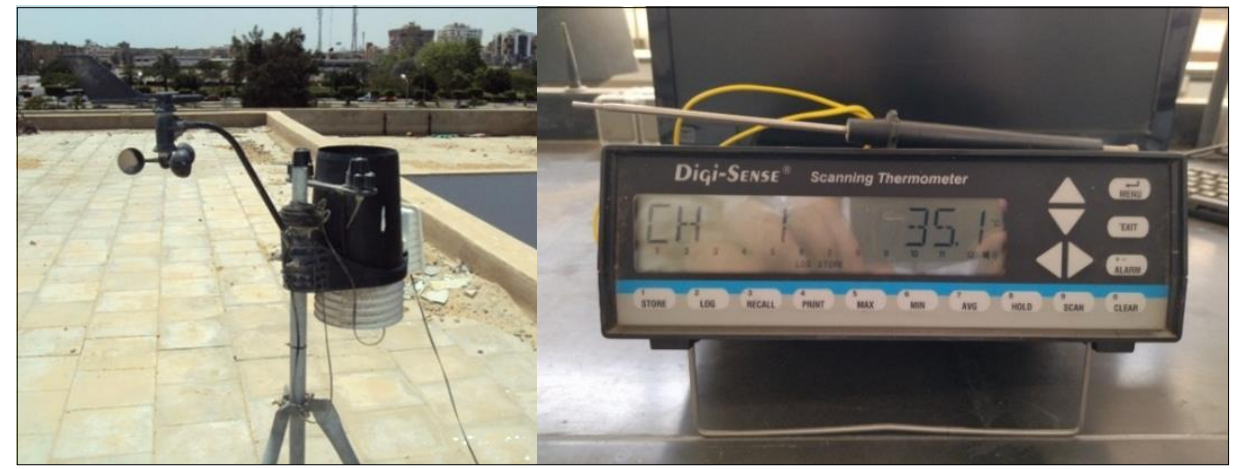

Fig. (3): Meteorological station and data logger system

\section{Methods}

Experiments were carried out under prevailing weather conditions of Ismailia region during July month of 2020. By keeping the depth of water in the basin at $2 \mathrm{~cm}$ (21 liter). During operating the solar stills, solar radiation was transmitted through the glass cover and absorbed by both the brackish water and the black metallic basin. Part of the absorbed energy by the basin is transferred by convection to the saline water. Condensate water was flowed by gravity into the collection trough at the lower edges of the tilted glass cover. Suez Canal water $(34,500 \mathrm{ppm})$ was used as feed. The yield from the still was collected and measured everyone hour during the daytime. The first conventional solar still was used as a control unit (S1). The second still was functioned with the cooling cellulose pad (S2). The third still was operated with the water sprinkler to spray saline water (S3). The concentration of hydrogen ion $(\mathrm{pH})$, electrical conductivity $(\mathrm{EC}, \mu \mathrm{s} / \mathrm{cm})$, and total dissolved solids (TDS, ppm) of the brackish water, respectively, were $7.8,48.5 \mu \mathrm{s} / \mathrm{cm}$ and $31040 \mathrm{ppm}$.

\section{Thermal efficiency of the solar still}

The thermal efficiency of the solar still from the experimental measurements (volumetric thermal efficiency) which represents the productivity of fresh water was mainly computed using the following formula Kantesh (2012):

$$
\eta=\frac{\mathrm{m} . \mathrm{L}}{3.6(\mathrm{~A} . \mathrm{I})}
$$

where, $\mathrm{m}$ is the rate at which distillate of fresh water is produced from the still in $\mathrm{kg} \mathrm{h}^{-1}, \mathrm{~L}$ is the latent heat of vaporization in $\mathrm{kJ} \mathrm{kg}^{-1}$ at an average basin water temperature $\left(\mathrm{T}_{\mathrm{w}}\right), \mathrm{A}$ is the surface area of basin in $\mathrm{m}^{2}$, and $\mathrm{I}$, is the solar radiation flux incident on the basin in $\mathrm{W} \mathrm{m}^{-2}$. The average latent heat (L) was determined by Kabeel and Abdelgaied, (2016) as follows:

$$
\mathrm{L}=10^{-3}\left(2501.9-2.40706 \mathrm{~T}_{\mathrm{w}}+1.192217 \times 10^{-3} \mathrm{~T}_{\mathrm{w}}{ }^{2}-1.5863 \times 10^{-5} \mathrm{~T}_{\mathrm{w}^{3}}\right)
$$

\section{RESULTS AND DISCUSSION}

For the duration of the experimental work, the three solar stills were operated satisfactorily without malfunction. The measurements of solar radiation intensity, various temperatures, and the production of distilled water were taken each hour. By keeping the depth of water in the basin at $2 \mathrm{~cm}$ (21 liter). Average ambient air temperature and solar radiation intensity during July month of 2020 are shown in Fig. (4). The intensity of solar radiation was gradually 
increased from sunrise $\left(144 \mathrm{Wm}^{-2}\right)$ till reached the maximum value $\left(739 \mathrm{Wm}^{-2}\right)$ at $13.00 \mathrm{~h}$, then it gradually decreased until approached the minimum value $\left(142 \mathrm{Wm}^{-2}\right)$ prior to sunset. The average intensities of solar radiation were $475.7 \mathrm{Wm}^{-2}$. While the ambient air temperature increased gradually from $27.4^{\circ} \mathrm{C}$ at $7.00 \mathrm{~h}$ until reached the maximum value $\left(35.2^{\circ} \mathrm{C}\right)$ at 13.00 $\mathrm{h}$, then it was decreased till reached $27.5^{\circ} \mathrm{C}$ at $19.00 \mathrm{~h}$. During the experimental period, the hourly average ambient air temperature was $32.1^{\circ} \mathrm{C}$.

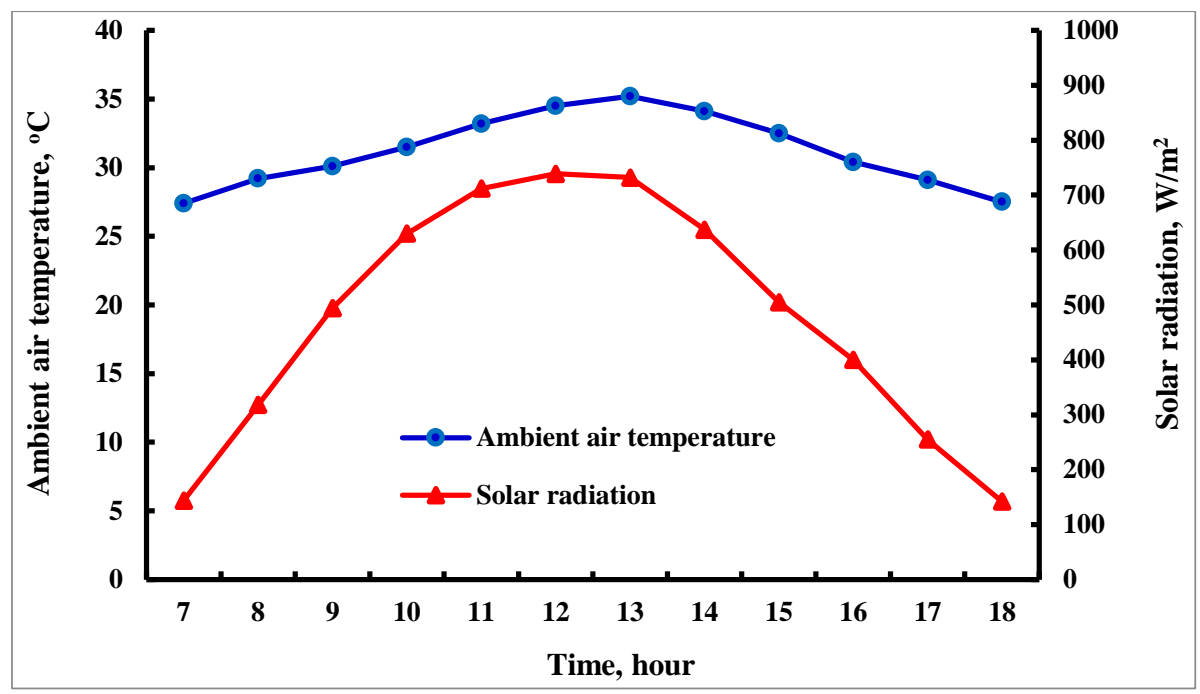

Fig. (4): Hourly average ambient air temperature and solar radiation during July month of 2020

The variations in temperatures at different locations of three different solar stills are presented in Fig. (5). As shown from the illustration, the temperatures have the same trend, as they increased in the morning hours and attain maximum values at around 13:00 $\mathrm{h}$ and decreased in the evening hours. This is obviously since the solar incident radiation increased in the morning but decreased in the afternoon. The vapour temperature had the largest temperature because the particles of vapour have enough heat energy (comprises sensible and latent heat) to evaporate. The highest vapour temperature was obtained between 13:00 pm and 14:00 $\mathrm{h}$ for all solar stills. It is noticed also that the average vapour temperature was found to be 57.1, 59.0 and $59.4^{\circ} \mathrm{C}$ for the S1, S2 and S3, respectively. From Fig. (5) it can clearly be seen that saline water temperatures increased for all tested solar stills reached the maximum values of $66.8,68.8$ and $69.3^{\circ} \mathrm{C}$ for the $\mathrm{S} 1, \mathrm{~S} 2$ and $\mathrm{S} 3$, respectively in afternoon $(13.00 \mathrm{~h})$ because to the absorbed solar radiation exceed the losses to the surrounding. After $13.00 \mathrm{~h}$, saline water temperature decreased because the heat energy losses from the solar stills which became larger than the absorbed solar radiation. Average saline water temperatures for solar stills around the daytime with one hour interval were found to be $55.0,56.3$ and $57.0^{\circ} \mathrm{C}$ for the $\mathrm{S} 1$, S2 and S3, respectively. The water temperature depends strongly upon the other different parameters such as the intensity of solar radiation, absorptivity of the water and black basin surface, and temperature difference between the water vapour and inside surface of the solar still. Also, Fig. (5) shows the effect of cellulose cooling water and spray water inside still on the inner glass cover temperature. It can be also noticed from Fig. (5) that the glass cover temperature was usually lower than that of the water temperature except in the early morning when the difference between them was very small. As the glass cover temperature is much lower than the water vapour temperature, it caused condensation of vapour on the internal 
surface of the glass. In the early morning hours $(7.00-8.00 \mathrm{~h})$, the glass temperature was close to the water and vapour temperatures resulting in small productivity due to the small heat energy absorbed by the water at these times.

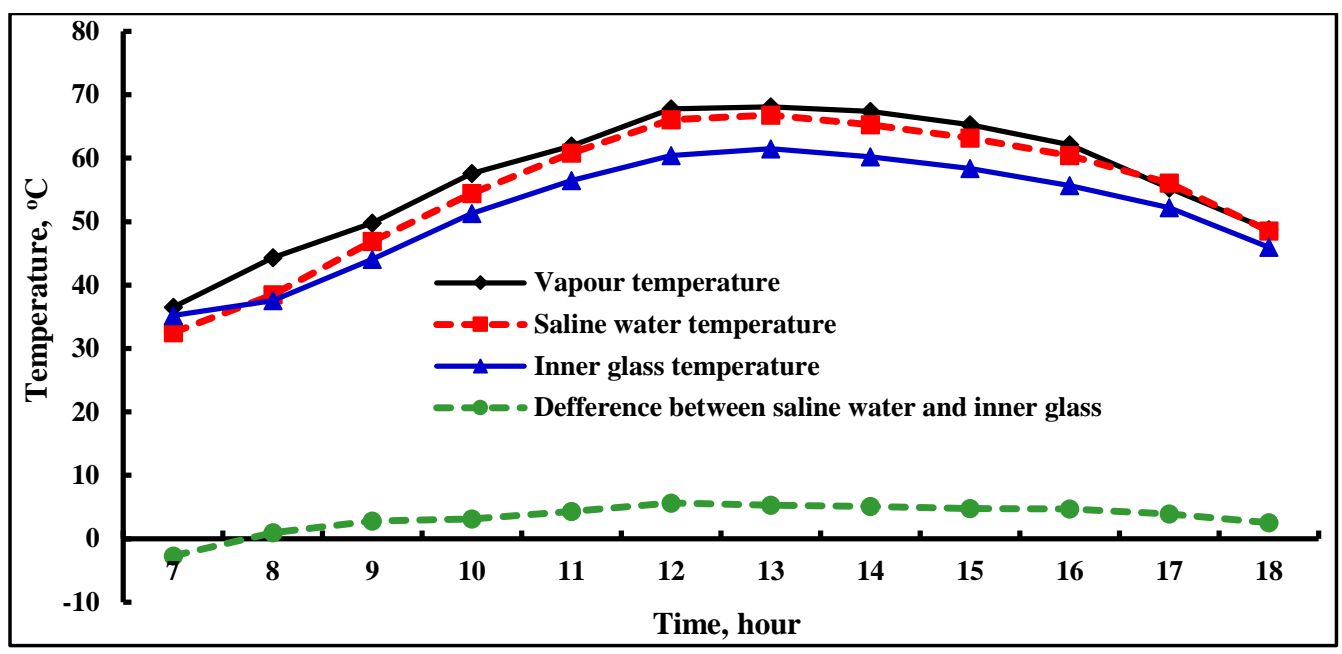

A - The conventional solar still (S1)

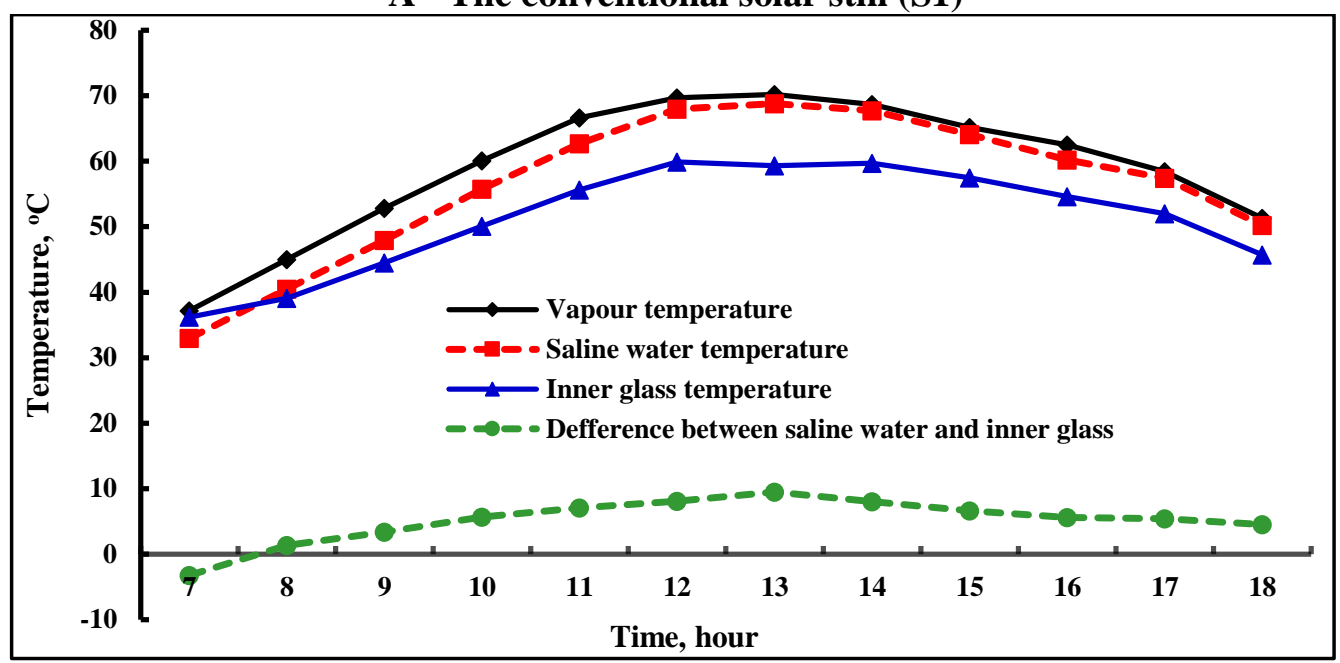

B - Solar still functioned with the cooling cellulose pad (S2)

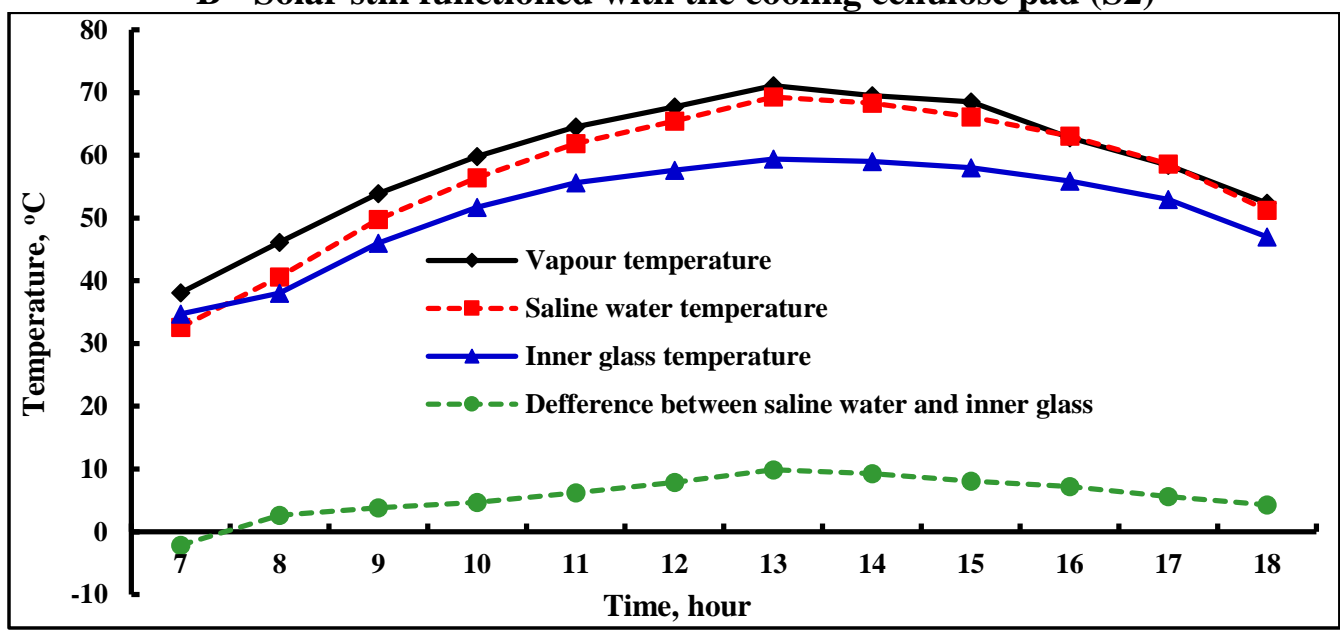

C - Solar still operated with the water sprinkler (S3)

Fig. (5): Hourly variation in temperature of solar stills 
The hourly average inner glass temperatures for solar stills were found to be 51.6, 51.2 and $51.4^{\circ} \mathrm{C}$ for the $\mathrm{S} 1, \mathrm{~S} 2$ and $\mathrm{S} 3$, respectively. The difference in temperature between saline water and inner glass throughout the day for the solar stills is plotted in Fig. (5). During early morning glass cover encountered the solar radiation first and its temperature rose very fast with time as compared with the rising in water temperature, and as a result the difference becomes negative. These differences remain negative till water temperature exceeded glass temperature. The maximum positive difference was found to be 5.7, 9.5 and $9.9^{\circ} \mathrm{C}$ which achieved at $14.00 \mathrm{~h} \mathrm{~S} 1, \mathrm{~S} 2$ and S3, respectively, after that the difference decreases till the sunset. The economical productivity rate of fresh water reflects how much the solar stills were adapted to the increase evaporation area. The yields $\mathrm{ml} / \mathrm{m}^{2} \mathrm{hr}$ for the different solar still trials are shown in Fig. (6). The productivity of fresh water for the three solar stills gradually increased from early morning until reached the maximum values $\left(495,565580 \mathrm{ml} / \mathrm{m}^{2} . \mathrm{hr}\right.$, respectively) afternoon then they decreased till approached the minimum values $(100,135$, and $158 \mathrm{ml} / \mathrm{m}^{2}$.hr) just prior to sunset. The cooling cellulose pad and spray water can be considered as one of the parameters that has a direct effect on the productivity of fresh water.

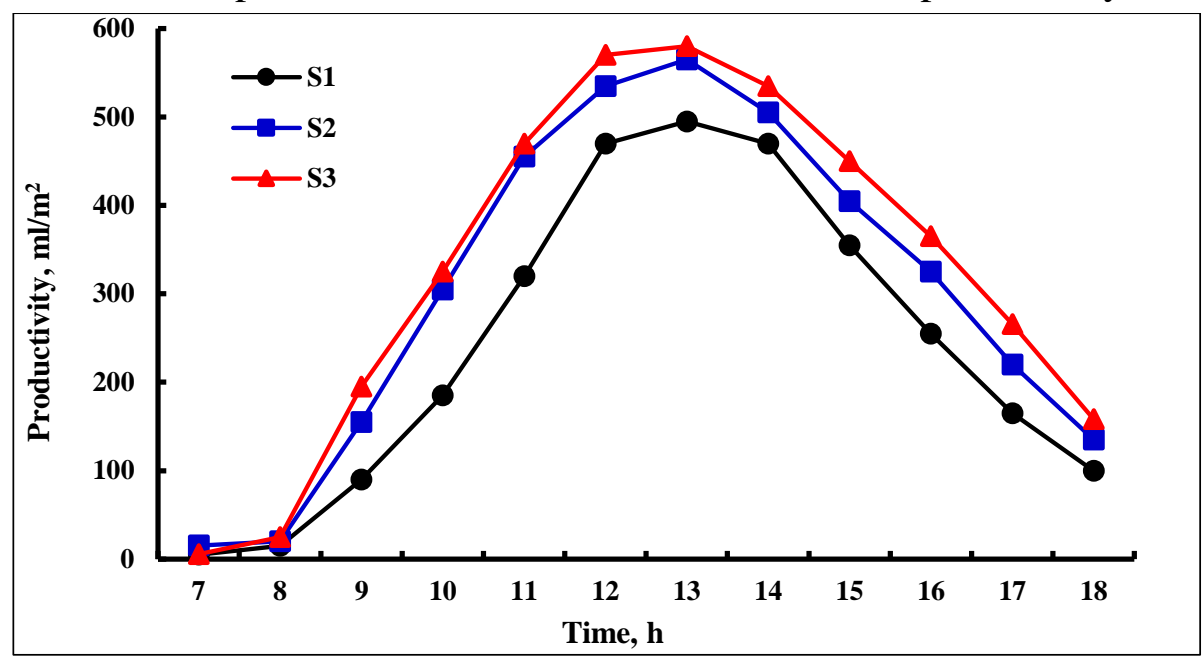

Fig. (6): Hourly average volumetric production rate as a function of solar time.

Daily average production of fresh water under the three different solar stills (S1, S2 and S3 stills), respectively, were 244, 303 and $329 \mathrm{ml} / \mathrm{hr}$. Results showed that, the solar intensity is directly proportional to the yield of fresh water from the solar still due to the increase in heat energy gained by the saline water at which vaporization inside the stills increased (Sathyamurthy et al., 2014). In the other hand, the accumulated freshwater yield for the solar stills depicts in Fig. (7). The total daily productivity of fresh water from the three solar stills approximately reached to 2925,3640 , and $3944 \mathrm{ml} / \mathrm{m}^{2}$ day, for the $\mathrm{S} 1, \mathrm{~S} 2$ and S3, respectively. This means that, the cooling cellulose pad and spray water increased the average production by 24.5 and $34.9 \%$ as compared with the control solar stills, respectively. The experimental results showed that, the daily average productivity of fresh water for the two solar stills with cooling cellulose pad and spray were higher than that of the conventional solar still. The highest productivity rate was achieved from the solar still with spray were due to the higher evaporative surface area. As a result, using cooling cellulose pad and spray in solar still was found to be the best option to increase the solar still productivity during the daylight-time. 


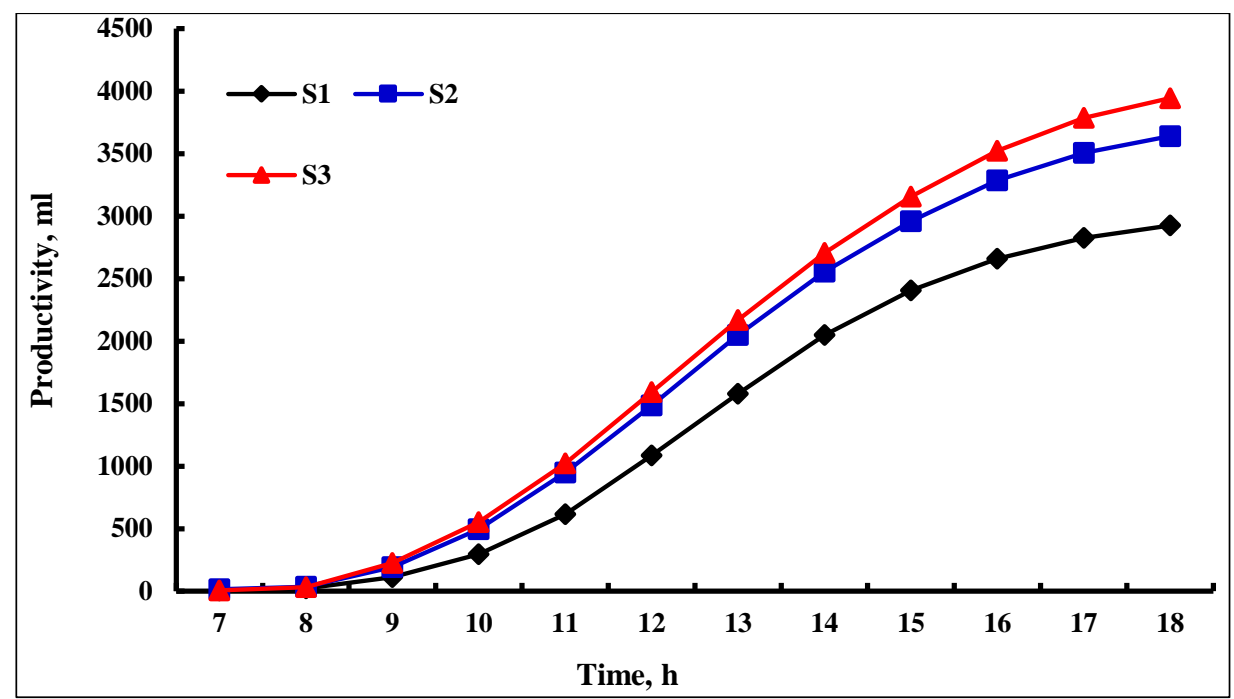

Fig. (7): Effect of PCM on the accumulated productivity of solar stills

The volumetric thermal efficiency of the solar still is considered the most important factor for evaluation because it can reveal the best solar still operation. The hourly average volumetric thermal efficiencies for each solar still type within a representative day under the average weather conditions are plotted in Fig. (8). In the same trend, the volumetric thermal efficiencies for the three solar still increased with the time until reaching the maximum value afternoon. For the duration of the experimental tests, the average solar still volumetric efficiency was found to be $31.5,40.1$ and $44.2 \%$ for the S1, S2 and S3, respectively. The results show that the volumetric thermal efficiency and productivity of solar still are directly proportional.

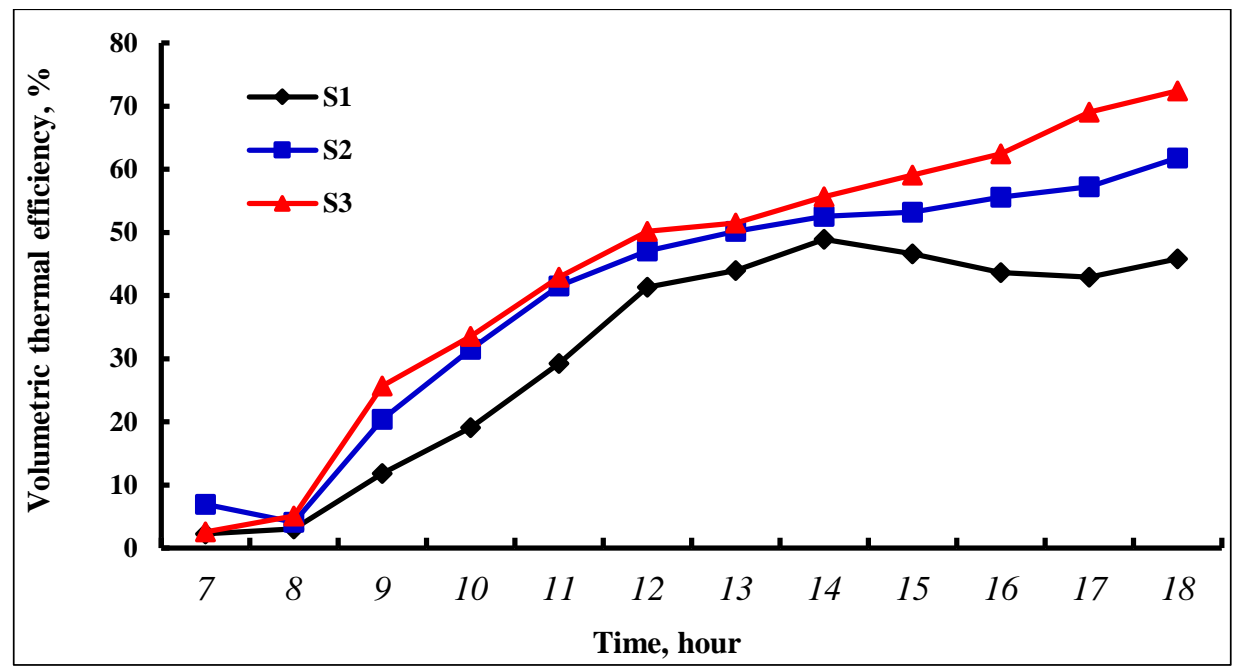

Fig. (8): Hourly average volumetric thermal efficiency versus time for the solar stills

\section{Distilled Water Quality}

The $\mathrm{pH}, \mathrm{EC}$ and TDS values of the sea water and the water distilled which obtained from the experimental work are summarized and listed in Table (1). These values were found to be much lower $(7.46,0.21 \mu \mathrm{s} / \mathrm{cm}$ and $134.4 \mathrm{ppm}$, respectively) than those of the sea water $(7.8$, $48.5 \mu \mathrm{s} / \mathrm{cm}$ and $31040 \mathrm{ppm}$, respectively). The quality of potable water distilled from solar still is suitable for drinking particularly in remote areas. 
Table (1): Quality parameters (pH, EC, and TDS) of the solar distilled water and sea water during the experimental tests

\begin{tabular}{lcc}
\hline \multicolumn{1}{c}{ Parameter } & Sea water & Distilled water \\
\hline $\mathrm{pH}$ & 7.8 & 7.46 \\
Electrical conductivity (EC), $\mu \mathrm{s} / \mathrm{cm}$ & 48.5 & 0.21 \\
Total Dissolved Solids (TDS), $\mathrm{ppm}$ & 31040 & 134.4 \\
\hline
\end{tabular}

\section{CONCLUSION}

In this present research work, several conclusions can be obtained and drawn as follows:

1- Daily average production of fresh water under the three different solar stills (S1, S2 and S3 stills), respectively, were 244, 303 and $329 \mathrm{ml} / \mathrm{hr}$. This means that, the cooling cellulose pad and spray water increased the average production by 24.5 and $34.9 \%$ as compared with the control solar stills, respectively.

2- The total daily productivity of fresh water from the three solar stills approximately reached to 2925,3640 , and $3944 \mathrm{ml} / \mathrm{m}^{2}$ day, for the $\mathrm{S} 1, \mathrm{~S} 2$ and $\mathrm{S} 3$, respectively.

3- The $\mathrm{pH}$ (7.46), EC $(0.21 \mu \mathrm{s} / \mathrm{cm})$, and TDS (134.4 ppm) values were lower than those of the brackish water $(7.8,48.5 \mu \mathrm{s} / \mathrm{cm}$ and $31040 \mathrm{ppm}$, respectively).

4- Using cooling pad and spray in solar still was found to be the best option to increase the solar still productivity during the daylight-time.

5- The hourly average solar still thermal efficiency was 31.5, 40.1 and $44.2 \%$ for the S1, $\mathrm{S} 2$ and S3, respectively

Finally, to overcome low productivity of solar still we can use cellulose cooling pad and water sprinklers to increase solar still efficiency.

\section{REFERENCES}

Abdallah, S.; and Badran, O. O. (2008) "Sun tracking system for productivity enhancement of solar still" Desalination, 220: 669-676.

Abu-Hijleh, B. A. K. and Rababa'h, H. M. (2003) "Experimental study of a solar still with sponge cubes in basin" Energy Conversion and Management; 44, 1411- 1418.

Arjunan1, T. V.; Aybar, H. S.; Nedunchezhian, N.; and Sakthivel, M. (2009) "Effect of Blue Metal Stones on the Performance of a Conventional Solar Still" Journal of Convergence in Engineering, Technology and Science, 1: 17-22.

Bassam, A. K.; Abu -Hijleh, B. A. K. and Rababa'h, H. M. (2003) "Experimental study of solar still with sponge cubes in basin" Journal of Energy Conversion Management, 44, 1411-1418.

Chukwujindu, N. S. (2017) "A Comprehensive Review of Empirical Models for Estimating Global Solar Radiation in Africa" Renewable an Sustainable Energy Reviews, 78, 955-995.

El-Sheikh, I. H. and Kishk, S. S. (2016) "Effect of Different Roof Configurations on Thermal Performance of Solar Stills" Misr Journal of Agricultural Engineering, 33 (3), 1033-1048. 
El-Zahaby, A. M.; Kabeel, A. E.; Bakry, A. I.; El-Agouz, S. A. and Hawam, O. M. (2011) "Enhancement of solar still performance using a reciprocating spray feeding systemAn experimental approach" Desalination, 267, 209 - 216.

Fath, H. E. S.; El-Samanoudy, M.; Fahmy, K.; and Hassabou, A. (2003) "Thermaleconomic analysis and comparison between pyramid-shaped and single slope solar still configurations" Desalination, 159: 69-79.

Goosen, M. F. A.; Sablani, S. S.; Shayya, W. H.; Paton, C.; and Al-Hinai, H. (2000) "Thermodynamic and economic considerations in solar desalination" Desalination, 129: 63-89.

Kabeel, A. E.; and Abdelgaied, M. (2016) "Improving the performance of solar still by using PCM as a thermal storage medium under Egyptian conditions" Desalination, 383: 22-28.

Kabeel, A. E.; Hamed, A. M.; and El-Agouz, S. A. (2010) "Cost analysis different solar still configurations" Energy, 35: 2901-2908.

Kantesh, D. C (2012) "Design of solar still using Phase changing material as a storage medium" International Journal of Scientific \& Engineering Research, 3, 12.

Kishk, S. S. and Abu-Zeid, M. A. (2019) "Experimental Evaluation of Two Serpentine Flat Plate Solar Water Heating Systems" Misr Journal of Agricultural Engineering, 36 (2):629-642.

Murugavel, K. K.; Chockalingam, Kn. K. S. K.; and Srithar, K. (2008) "Progresses in improving the effectiveness of the single basin passive solar still" Desalination, 220: 677-686.

Nandurkar, Y. Y. and Shelke, R. S. (2012) "Review of performance and analysis of Isi flat plate collector with modified flat plate collector" International Journal of Engineering Science and Technology (IJEST), 4 (3), 944-946.

Phadatare, M. K and Verma, S. K. (2007) "Influence of water depth on internal heat and mass transfer in a plastic solar still" Desalination, 217, 267 - 275.

Rai, A. K.; Singh, N.; and Sachan, V. (2013) "Experimental study of a single basin solar still with water cooling of the glass cover" International Journal of Mechanical Engineering \& Technology (IJMET), 4 (2), 1 - 7.

Rajesh, T.; and Tiwari, G. N. (2005) "Effect of water depth on internal heat and mass transfer for active solar distillation" Desalination, 173: 187-200.

Sakthivel, M.; Shanmugasundaram S.; and Alwarsamy, T. (2010) "An experimental study on a regenerative solar still with energy storage medium Jute cloth" Desalination, 264: $24-31$

Singh, H. N.; and Tiwari, G. N. (2004) "Monthly performance of passive and active solar stills for different Indian climatic conditions" Desalination, 168: 145-150.

Sundaram, P.; Mohan, D. S.; and Kumar, M. P. (2016) "Evaluation of pyramidal slope solar still integrated with PCM thermal storage" International Journal of Chem. Tech. Research, 9 (9): 230 - 236.

Taha, A. T and Helal, M. M. (2020) "Engineering study on absorbent surfaces to improve the performance of solar collectors" Misr Journal of Agricultural Engineering, 37 (4), 393-406. 


\section{تحسين كفاءة المقطرات الثمسية باستخدام وسائد التبريد ورشاشات المياه سامح سعيد كثك}

' أستاذ مساعد ـ قسم الهندسة الزر اعية ـ كلية الزر اعة ـ جامعة قناة السويس

\begin{tabular}{|c|c|}
\hline 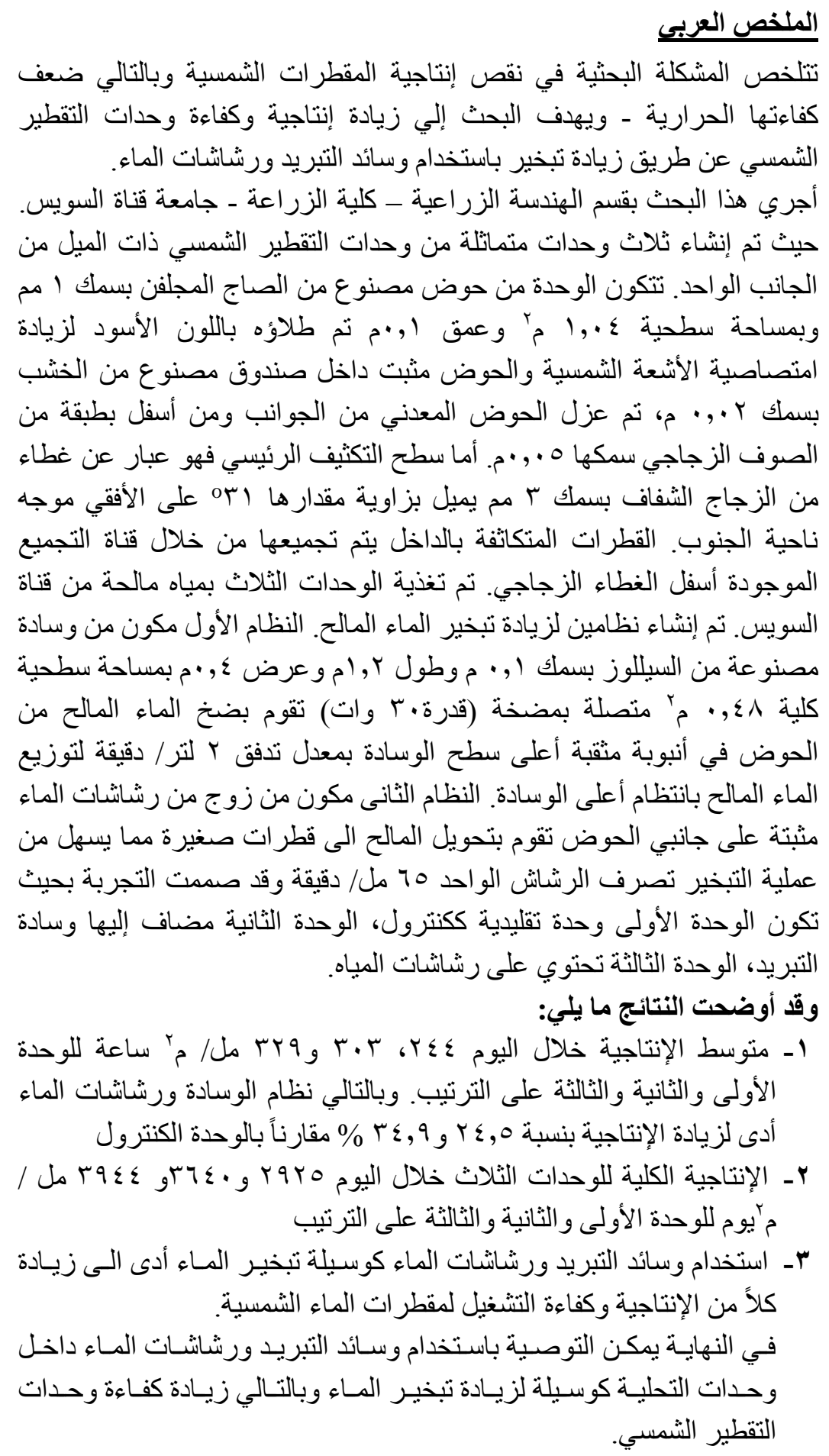 & الكقطر ات الثمسية؛ رشاتية: الثفاثات مياه؛ \\
\hline
\end{tabular}

